\title{
Karakteristik Wanita Usia Subur Dengan Tindakan Pencegahan Kanker Serviks
}

\author{
Supatmi $^{1,2}$, Calvenia Nur Putri Parwati ${ }^{1}$, Septian Galuh $\mathbf{W}^{1}$
}

Faculty Health of Science Universitas Muhammadiyah Surabaya, Indonesia

Doctoral Student Faculty Nursing, Universitas Airlangga, Surabaya, Indonesia

\section{Correspondence :}

Supatmi

Faculty Health of Science Universitas Muhammadiyah Surabaya, Indonesia

Email : supatmioppi@gmail.com

Tanggal Submit:
5 Mei 2020
Tanggal Review:
5 Oktober 2020
Tanggal Publish
Online:
10 Desember 2020

Tanggal Submit:

Tanggal Review:

5 Oktober 2020

Online:

10 Desember 2020

\begin{abstract}
Background: The awareness of Indonesian women to carry out early detection of cervical cancer on a regular basis have been still low. Cervical cancer can be prevented and cured by taking early detection measures because it has a long preinfassive phase. Cervical cancer prevention measures are influenced by several factors including age, education level, occupation and parity,

Aims: analyze the characteristics of women of childbearing age with cervical cancer prevention measures (HPV, IVA and Pap smear immunization)

Methods: Quantitative analytic research design with cross sectional approach. The population was 193 women of fertile age in RW 9 Kelurahan Kapasan Surabaya with n Cluster Samples, the sample was 130 WUS. The research instrument used a characteristic questionnaire and cervical cancer prevention measures with a Dichotomy Question. The research variables were WUS cataristic and cervical cancer prevention behavior. Analysis with Chi-Square with a significance level of 0.05

Results: There was a relationship between age and HPV immunization $(\mathrm{p}=0.066)$ and pap smear $(\mathrm{p}=0.058)$, IVA action had not relationship $(\mathrm{p}=0.770)$, education was related to HPV immunization $(p=0.346)$. IVA $(0.005)$ was not related to pap smears $=0.603)$ Occupation was related to HPV immunization $(\mathrm{p}=0.280)$, IVA $(\mathrm{p}=0.000)$ and pap smears $(\mathrm{p}=$ $0.216)$, parity was related to HPV immunization $(p=0.003))$ and Pap smear $(\mathrm{p}=0.117)$ meanwhile parity had not relationship with IVA $(p=0.839)$. Studying the characteristics of WUS is a first step to increase preventive efforts for cervical cancer both primary and secondary prevention
\end{abstract}

Keyword: Characteristics of WUS, Prevention, Cervical Cancer 


\section{PENDAHULUAN}

Kejadian kanker serviks lebih sering di negara berkembang dibandingkan dengan negara maju. Kanker seviks dapat dicegah dan disembuhkan dengan melakukan tindakan deteksi dini karena memiliki fase preinfasif yang panjang, (Aweke et al,, 2017). Lebih dari 80\% kanker serviks didiagnosis pada stadium lanjut, yang seringkali sangat buruk prognosisnya.. Diperkirakan hanya 5\% wanita di negara berkembang yang menjalani pemeriksaan pap smear, sedangkan di negara maju mencapai 50\% (Shrestha et al, 2013). Di negara berkembang, hanya sekitar 5\% wanita yang menjalani skrining berbasis sitologi dalam periode 5 tahun terakhir dikarenakan kurang tersedianya sumber daya perawatan kesehatan untuk menopang program, terbatasnya layanan untuk rumah sakit, pendidikan, laboratorium swasta di terbatas di perkotaan dan selanjutnya keterlambatan pelaporan hasil sitologi yang menghambat program skrining berbasis sitologi menjadi efektif di negara berkembang (WHO, 2009). Kesadaran perempuan Indonesia untuk melakukan deteksi dini kanker serviks secara teratur masih rendah.(Priyanto, 2010)

Data Global Cancer Observatory (2018) melaporkan bahwa Indonesia menduduki peringkat kedua kasus kanker serviks terbanyak di dunia dengan jumlah kasus diperkirakan sebanyak 32.469 kasus per tahunnya (Bray et al., 2018) Data yang diperoleh dari salah satu rumah sakit di Surabaya menunjukkan terdapat 8 sampai 10 pasien kanker serviks baru setiap harinya, dimana $70 \%$ dari mereka sudah berada dalam tahap stadium lanjut, yang harapan sembuhnya sangat kecil. Provinsi Jawa Timur merupakan provinsi dengan estimasi penderita kanker terbanyak di Indonesia. setelah Daerah Istimewa Yogyakarta (DIY), yaitu berjumlah $1,1 \%$ atau 21.313 kasus (Dinkes Jatim,2018). Hasil data riset penyakit tidak menular 2016 yang dilakukan oleh Balitbangkes Kemenkes RI tahun 2016 menunjukkan bahwa wanita usia 25-64 tahun yang pernah melakukan pemeriksaan IVA baru sebesar $3,52 \%$ sementara yang pernah melakukan papsmear sebesar $7,71 \%$ (Kemenkes RI, 2016). Di Surabaya jumlah wanita usia subur sebanyak 9.425 wanita dan yang melakukan pemeriksaan skrinning tes IVA sebanyak 10.601 wanita atau 2,21\%. (Dinas Kesehatan, 2016).

Strategi dalam pencegahan kanker serviks yang terbaik adalah dengan melakukan vaksinasi (pencegahan primer) dan screening berupa pap smear 
(pencegahan sekunder) untuk menjangkau infeksi virus Human Papiloma Virus (HPV), karena jangkauan perlindungan vaksinasi tidak mencapai $100 \%$, yaitu hanya sekitar $89 \%$. Vaksinasi tidak bertujuan untuk terapi melainkan mencegah infeksi yang bekerja dengan cara meningkatkan antibodi d alam tubuh. Screening pap smear mampu mendeteksi perubahan pada serviks secara dini sebelum berkembang menjadi kanker sehingga dapat disembuhkan dengan segera (Andrijono, 2009), seiring waktu, vaksinasi akan menurunkan prevalensi penyakit di antara wanita yang lebih muda tetapi skrining masih diperlukan (Gannon \& Dowling, 2008) dilanjutkan dengan melakukan pencegahan sekunder. Pencegahan sekunder dengan melakukan skrining IVA dan pap smear mampu mendeteksi perubahan pada serviks secara dini sebelum berkembang menjadi kanker sehingga dapat disembuhkan dengan segera (Andrijono, 2009). Tindakan pencegahan yang dapat dilakukan dengan metode dan peralatan sederhana adalah deteksi dini dengan IVA namun cakupan pemeriksaan IVA di Indonesia sejak tahun 2007-2016 hanya 5,15\%. (Armini et al, 2015)

Tindakan pencegahan kanker servik merupakan perilaku kesehatan yang dipengaruhi oleh beberapa faktor salah satunya yaitu predisposing factor (Notoadmodjo, 2010) yang meliputi usia, tingkat pendidikan, pekerjaan dan paritas,, (karakteristik individu). Dengan mendapatkan pengetahuan tentang kanker serviks, vaksinasi HPV, skrining tes IVA dan Pap Smear mampu memberi motivasi wanita usia subur untuk menjalani pola hidup lebih sehat dan bisa menurunkan angka kejadian kanker serviks (Habtu et al, 2020)

\section{METODE PENELITIAN}

Penelitian ini menggnakan desain analitik kuantitatif dengan pendekatan cross sectional. Populasi pada penelitian ini adalah Wanita Usia Subur (WUS) di RW 9 Kelurahan Kapasan Kota Surabaya sebanyak 193 dilakukan teknik Probability Sampling dengan menggunakan Cluster Samplin. Besar sampel 130 WUS. Intrument penelitian ini menggunakan kuesioner yang berisi tentang karakteristik responden dan untuk tindakan pencegahan kanker servik dengan Dichotomy Question. Variabel penelitian adalah katareristik wanita usia subur dan perilaku pencegahan kanker serviks. Pengumpulan data dilakukan dengan door to door pada bulan Juni 2019. Analisis data menggunakan Chi-Square dengan tingkat kemaknaan 0,05. 
HASIL

Dalam penelitian ini responden $(\mathrm{N}=130)$ diberi kuesioner dan sebelumnya diberikan inform consent. Kuesioner kemudian dikumpulkan dan diperiksa isinya. Kuesioner yang lengkap dan valid digunakan untuk entri SPSS.

Ditemukan mayoritas responden berusia 31-40 tahun $(\mathrm{N}=72)$ dengan Pendidikan SLTA $(N=67)$, Ibu Rumah tangga $(\mathrm{N}=82)$, memiliki 1-2 anak $(\mathrm{N}=$ 93), mengetahui pencegahan kanker servik (N=97) Karakteristik responden (Tabel 1)

Tabel 1. Karakteristik Wanita Usia Subur(N $=130$ )

\begin{tabular}{ll}
\hline Variabel & N (\%) \\
\hline Usia & \\
$20-30$ & $47(36,0 \%)$ \\
$31-40$ & $72(55,0 \%)$ \\
$41-50$ & $11(9,0 \%)$
\end{tabular}

\section{Pendidikan}

SD

SLTP

SLTA

Diploma

Sarjana

Pekerjaan

Bekerja

Ibu rumah Tangga

Paritas

Tidak memiliki anak

1-2

3-4

$\geq 5$

\section{Pengetahuan}

Tahu

Tidak tahu
$15(11,5 \%)$

$32(24,6 \%)$

$67(51,5 \%)$

$9(6.9 \%)$

$7(5.5 \%)$

$48(36,9 \%)$

$82(63,1 \%)$

$3(2.3 \%)$

$93(71,5 \%)$

$33(25,4 \%)$

$1(0,8 \%)$

$97(75,0 \%)$

$33(25,0 \%)$
Tindakan pencegahan kanker serviks sebagian besar belum pernah melakukan imunisasi $\operatorname{HPV}(\mathrm{N}=125)$, IVA $(\mathrm{N}=105)$ dan Pap smear $(\mathrm{N}=113)$. Tabel 2 . Tindakan pencegahan kanker serviks

Tabel 2. Tindakan pencegahan kanker servik $(\mathrm{N}=130)$

\begin{tabular}{lr}
\hline \multicolumn{1}{c}{ Variabel } & $\mathbf{N}(\%)$ \\
\hline Imunisasi HPV & $5(4,0 \%)$ \\
Pernah & $125(96,0 \%)$ \\
Tidak Pernah & \\
IVA & $25(12,0 \%)$ \\
Pernah & $105(88,0 \%)$ \\
Tidak pernah & \\
Pap smear & $17(13,0 \%)$ \\
Pernah & $113(87,0 \%)$ \\
Tidak pernah & \\
&
\end{tabular}

Analisis Chi Square karakteristik dengan tindakan pencegahan kankes serviks di dapatkan ada hubungan antara umur dengan tindakan Imunisasi HPV ( $p=0,066)$ dan pap smear $(\mathrm{p}=0,058)$ sedangan dengan tindakan IVA tidak ada hubungan ( $p=0,770)$, sedangan tingkat Pendidikan ada hubungan dengan imunisasi HPV $(\mathrm{p}=0.346)$. IVA $(0,005)$, tidak ada hubungan dengan pap smear $(\mathrm{p}=0,603)$ Pekerjaan ada hubungan dengan Imunisasi HPV $\quad(p=0,280), \quad$ IVA $(\mathrm{p}=0,000)$ dan pap smear $(\mathrm{p}=0,216)$, sedangkan untuk paritas ada hubungan dengan tindakan Imunisasi HPV $(\mathrm{p}=0,003)$ danpap Pap smear $(\mathrm{p}=0,117)$ 
sedangan paritas tidak ada hubungan

dengan tindakan IVA $(\mathrm{p}=0,839)$

Tabel.3. Karakteristik WUS dengan tindakan penceghan Kanker servik

\begin{tabular}{|c|c|c|c|c|c|c|}
\hline Variabel & \multicolumn{2}{|l|}{ HPV } & \multicolumn{2}{|l|}{ IVA } & \multicolumn{2}{|c|}{ Pap Smear } \\
\hline Umur & $\begin{array}{r}\text { Tidak } \\
\text { pernah }\end{array}$ & pernah & $\begin{array}{l}\text { Tidak } \\
\text { pernah }\end{array}$ & Pernah & \begin{tabular}{|l|} 
Tidak \\
pernah
\end{tabular} & pernah \\
\hline $20-30$ & 44 & 3 & 38 & 9 & 45 & 2 \\
\hline $31-40$ & 70 & 2 & 59 & 13 & 58 & 14 \\
\hline \multirow[t]{2}{*}{$41-50$} & 11 & 0 & 8 & 3 & 9 & 2 \\
\hline & \multicolumn{2}{|c|}{$\mathrm{P}=0,066$} & \multicolumn{2}{|c|}{$\mathrm{P}=0,770$} & \multicolumn{2}{|l|}{$\mathrm{P}=0,058$} \\
\hline \multicolumn{7}{|l|}{$\begin{array}{l}\text { Pendidik } \\
\text { an }\end{array}$} \\
\hline SD & 15 & 0 & 14 & 1 & 14 & 1 \\
\hline SLTP & 31 & 0 & 29 & 2 & 28 & 3 \\
\hline SLTA & 66 & 2 & 54 & 14 & 57 & 11 \\
\hline Diploma & 8 & 1 & 4 & 5 & 8 & 1 \\
\hline \multirow[t]{2}{*}{ Sarjana } & 7 & 0 & 4 & 3 & 5 & 2 \\
\hline & \multicolumn{2}{|c|}{$\mathrm{P}=0,346$} & \multicolumn{2}{|c|}{$\mathrm{P}=0,005$} & \multicolumn{2}{|c|}{$\mathrm{P}=0,603$} \\
\hline \multicolumn{7}{|l|}{$\begin{array}{l}\text { Pekerjaa } \\
\mathrm{n}\end{array}$} \\
\hline Bekerja & 46 & 2 & 31 & 17 & 39 & 9 \\
\hline \multirow[t]{2}{*}{ IRT } & 81 & 1 & 74 & 8 & 73 & 9 \\
\hline & \multicolumn{2}{|c|}{$\mathrm{P}=0,280$} & \multicolumn{2}{|c|}{$\mathrm{P}=0,000$} & \multicolumn{2}{|c|}{$\mathrm{P}=0,216$} \\
\hline \multicolumn{7}{|l|}{ Paritas } \\
\hline $\begin{array}{l}\text { Tanpa } \\
\text { anak }\end{array}$ & 2 & 1 & 2 & 1 & 2 & 1 \\
\hline $1-2$ & 92 & 2 & 77 & 17 & 85 & 9 \\
\hline $3-4$ & 32 & 0 & 25 & 7 & 24 & 8 \\
\hline \multirow[t]{2}{*}{$>5$} & 1 & 0 & 1 & 0 & 1 & 0 \\
\hline & \multicolumn{2}{|c|}{$\mathrm{P}=0,003$} & \multicolumn{2}{|c|}{$\mathrm{P}=0,839$} & \multicolumn{2}{|c|}{$\mathrm{P}=0,117$} \\
\hline
\end{tabular}

\section{PEMBAHASAN}

Dalam penelitian ini umur responden berhubungan dengan tindakan pencegahan kanker serviks (Imunisasi HPV $\quad(p=0.066)$ dan Pap smer $(\mathrm{p}=0,058)$. Usia responden berada dalam rentang 31-40 tahun (55\%). Sasieni et al (2003) menyimpulkan bahwa mulai pemeriksaan serviks usia 25 tahun karena kanker invasif sangat jarang tetapi bersifat sitologis kelainan biasa terjadi dengan umur kurang dari 25 tahun, (Sasieni, et al 2003).
Demikian pula, Bano et al (2008) juga mendukung skrining awal pada wanita muda yang aktif secara seksual. Mereka berpendapat bahwa HPV Infeksi adalah penyakit menular seksual yang paling umum dan dapat diperoleh segera setelah memulai hubungan seksual pertama hubungan, waktu median hanya 3 bulan. Jadi, wanita muda yang aktif secara seksual berisiko terkena infeksi HPV dan CIN berikutnya (Bano et al., 2008)

Penelitian ini menunjukan hubungan yang signifikan antara pendidikan responden dengan tindakan pencegahan kanker serviks (Imunisasi HPV $(p=0,346)$ dan IVA $(\mathrm{p}=0,005)$. Mayoritas responden berpendidikan SLTA (51,5\%), esuai dengan penelitian yang dilakukan oleh Morema et al. di Kenya dengan p $<0,0001$ (Morema et al, 2014, Acharya et al, 2017) Demikian penelitian yang dilakukan oleh Tracy di AS menunjukkan bahwa pemeriksaan rutin lebih banyak kemungkinan besar telah lulus perguruan tinggi ( $\mathrm{p}=0,01)$ (Tracy, Schluterman, \& Greenberg, 2013). Tingkat Pendidikan seseorang berpengaruh terhadap pengetahuan. Diketahui bahwa pengetahuan tentang faktor penyebab dan metode pencegahan sangat penting dalam pencegahan kanker serviks. Pengetahuan 
memengaruhi pengambilan keputusan individu karena mengetahui faktorfaktor ini dapat memengaruhi seseorang menghindari atau mengatasinya dan karenanya melarikan diri dari tertular penyakit (Abamecha, Tena, \& Kiros, 2019)

Pekerjaan berhubungan dengan tindakan pencegahan cervik (Imunisasi HPV $(p=0,280), \operatorname{IVA}(p=0,000)$ dan Pap smear $(\mathrm{p}=0,216)$. Hasil penelitian ini sesuai dengan teori yang mengatakan bahwa perilaku pencegahan ditentukan salah satunya oleh faktor yang berasal dari diri sendiri, yaitu pendidikan, pekerjaan dan pendapatan serta pengetahuan. Pendapatan atau penghasilan merupakah salah satu faktor yang juga berpengaruh terhadap perilaku baik dalam melakukan upaya pencegahan penyakit (Wuryaningsih, 2008)

Parietas responden berhubungan dengan tindakan pencegahan kanker servik ( Imunisasi HPV $(p=0,003)$ dan pap smear $(p=0,117)$. Hasil ini senada dengan penelitian Hakimah (2016) yang menyebutkan bahwa sebagian besar yang melakukan pemeriksaan Pap Smear untk deteksi dini kanker serviks adalah kelompok yang berisiko yaitu multipara. Hasil penelitian ini menunjukkan bahwa semakin tinggi paritas ibu semakin tinggi pula minat ibu untuk melakukan deteksi dini kanker serviks. Hal ini karena ibu merasakan kerentaranan yang ada pada dirinya (perceived susceptibility) Dalam teori health belief model ada beberapa variabel yang mendasari dalam perubahan perilaku kesehatan salah satunya variabel kerentanan yang dirasakan akibat kanker serviks merupakan persepsi pribadi tentang kemungkinan terkena kanker (Nugraheni et al., 2017) Ketika ibu merasa dirinya rentan terhadap suatu penyakit maka ibu akan memiliki upaya pencegahan yang lebih kuat daripada yang tidak memiliki persepsi kerentan.

\section{KESIMPULAN}

Karakteristik wanita usia subur /WUS ( Umur, Pendidikan, pekerjaan dan paritas) berhubungan dengan tindakan pencegahan kanker servik ( Pencegahan primer/ Imunisasi HPV) pekerjaan yang berhubungan dengan semua tindakan pencegahan kanker servik baik primer maupun skunder, sedangkan umur, pendidikan dan paritas berhunungan dengan salah satu dari pencegahan sekunder (IVA dan pap smear) . Mempelajari karakteristik Wanita usia subur sebagai langkah awal dalam upaya meningkatkan upaya preventif untuk kanker cervik baik pencegahan primer mapun sekunder 


\section{DAFTAR PUSTAKA}

Abamecha, F., Tena, A., \& Kiros, G. (2019). Psychographic predictors of intention to use cervical cancer screening services among women attending maternal and child health services in Southern Ethiopia: The theory of planned behavior (TPB) perspective. BMC Public Health, 19(1), 1-9. https://doi.org/10.1186/s12889019-6745-x

Acharya Pandey, R., \& Karmacharya, E. (2017). Cervical cancer screening behavior and associated factors among women of Ugrachandi Nala, Kavre, Nepal. European Journal of Medical Research, 22(1), 1-9. https://doi.org/10.1186/s40001017-0274-9

Andrijono. (2009). Kanker serviks. Onkologi, Departemen ObstetriGinekologi Fakultas Kedokteran Universitas Indonesia.

Armini N, K, A, Kusumaningrum T, Z. F. (2015). Motivasi wanita usia produktifyang beresiko kanker me lakukan pemeriksaan IVA. 184189.

Aweke, Y. H., Ayanto, S. Y., \& Ersado, T. L. (2017). Knowledge, attitude and practice for cervical cancer prevention and control among women of childbearing age in Hossana Town , Hadiya zone, Southern Ethiopia: Communitybased cross-sectional study. (July). https://doi.org/10.1371/journal.pon e. 0181415
Bano, F., Kolhe, S., Zamblera, D., Jolaoso, A., Folayan, O., Page, L., \& Norton, J. (2008). Cervical screening in under 25s: A high-risk young population. European Journal of Obstetrics and Gynecology and Reproductive Biology, 139(1), 86-89. https://doi.org/10.1016/j.ejogrb.20 07.08.020

Bray, F., Ferlay, J., Soerjomataram, I., Siegel, R. L., Torre, L. A., \& Jemal, A. (2018). Global cancer statistics 2018: GLOBOCAN estimates of incidence and mortality worldwide for 36 cancers in 185 countries. CA: A Cancer Journal for Clinicians, 68(6), 394424.

https://doi.org/10.3322/caac.21492

Dinas Kesehatan. (2016). Profil kesehatan.

Gannon, M., \& Dowling, M. (2008). Increasing the uptake of cervical screening programmes. British Journal of Nursing (Mark Allen Publishing), 17(20), 1280-1284. https://doi.org/10.12968/bjon.2008. 17.20.31642

Habtu, Y., Yohannes, S., \& Laelago, T. (2020). Health seeking behavior and its determinants for cervical cancer among women of childbearing age in Hossana Town , Hadiya zone, Southern Ethiopia: community based cross sectional study. (February). 
Morema, E. N., Atieli, H. E., Onyango, R. O., Omondi, J. H., \& Ouma, C. (2014). Determinants of Cervical screening services uptake among 18-49 year old women seeking services at the Jaramogi Oginga Odinga Teaching and Referral Hospital, Kisumu, Kenya. BMC Health Services Research, 14(1). https://doi.org/10.1186/1472-696314-335

Notoadmodjo. (2010). Promosi Kesehatan Teori dan Aplikas. Jakarta: PT Rineka Cipta.

Nugrahani, R. R., Budihastuti, U. R., \& Pamungakasari, E. P. (2017). Health Belief Model on the Factors Associated With the Use of Hpv Vaccine for the Prevention of Cervical Cancer Among Women in Kediri, East Java. 2, 90. https://doi.org/10.26911/theicph.20 17.009

Priyanto, H. (2010). Kanker Serviks. Jakarta: Tiga Kelanan.

Sasieni, P., Adams, J., \& Cuzick, J. (2003). Benefit of cervical screening at different ages: Evidence from the UK audit of screening histories. British Journal of Cancer, 89(1), 88-93. https://doi.org/10.1038/sj.bjc.6600 974
Shrestha, J., Saha, R., \& Tripathi, N. (2013). Knowledge, Attitude and Practice regarding Cervical Cancer Screening Amongst Women visiting Tertiary Centre in Kathmandu, Nepal. Nepal Journal of Medical Sciences, 2(2), 85-90. https://doi.org/10.3126/njms.v2i2.8 941

Timur, P. J. (2018). Profil kesehatan.

Tracy, J. K., Schluterman, N. H., \& Greenberg, D. R. (2013). Understanding cervical cancer screening among lesbians: A national survey. BMC Public Health, 13(1), 1-8. https://doi.org/10.1186/1471-2458$13-442$

WHO. (2009). Prevention of cervical cancer through screening using visual inspection with acetic acid (VIA) and treatmentwith cryotherapy.

Wuryaningsih. (2008). Hubungan Antara Pengetahuan dan Persepsi dengan Perilaku Masyarakat dalam Pemberantasan Sarang Nyamuk Demam Berdarah Dengue (PSN DBD) di Kota Kediri. 